\title{
Postharvest Treatments with GRAS Salts to Control Fresh Fruit Decay
}

\author{
Lluís Palou \\ Laboratori de Patologia, Centre de Tecnologia Postcollita (CTP), Institut Valencià d'Investigacions \\ Agràries (IVIA), 46113 Montcada, Valencia, Spain; palou_llu@gva.es; Tel.: +34-963-424-117
}

Received: 30 October 2018; Accepted: 20 November 2018; Published: 23 November 2018

\begin{abstract}
Control of postharvest diseases of fresh fruits has relied for many years on the continuous use of conventional chemical fungicides. However, nonpolluting alternatives are increasingly needed because of human health and environmental issues related to the generation of chemical residues. Low-toxicity chemicals classified as food preservatives or as generally recognized as safe (GRAS) compounds have known and very low toxicological effects on mammals and minimal impact on the environment. Among them, inorganic or organic salts such as carbonates, sorbates, benzoates, silicates, etc., show significant advantages for potential commercial use, such as their availability, low cost, and general high solubility in water. Typically, these substances are first evaluated in vitro against target pathogens that cause important postharvest diseases. Selected salts and concentrations are then assayed as aqueous solutions in in vivo tests with target fresh fruit. Laboratory and small-scale experiments are conducted with fruit artificially inoculated with pathogens, whereas naturally infected fruit are used for large-scale, semicommercial, or commercial trials. Another approach that is increasingly gaining importance is evaluating GRAS salts as antifungal ingredients of novel synthetic edible coatings. These coatings could replace the fungicide-amended commercial waxes applied to many fruit commodities and could be used for organic or "zero-residue" fresh fruit production systems.
\end{abstract}

Keywords: fresh fruits; postharvest disease; fungicide-free control; low-toxicity chemical control; antifungal edible coatings

\section{Introduction}

Pathogenic filamentous fungi are the most important causal agents of postharvest decay of fresh fruits. Depending on the fruit species, cultivar, and a wide range of pre- and postharvest factors and conditions, the incidence of fungal decay can cause considerable economic losses to growers and traders, especially if the produce is intended for export markets. Wholesale buyers often reject fruit loads if decay is found in export shipments, and furthermore, they may charge the producer for the transport and handling costs [1].

Every fresh fruit commodity is prone to decay caused by pathogenic fungi. Depending on the origin and characteristics of the infection, fungi that cause postharvest diseases can be classified into two general groups: (i) those that infect the fruit in the field and remain latent until their development after harvest, and (ii) those that infect the fruit through rind microwounds or injuries inflicted during harvest, transportation, postharvest handling, and commercialization [2]. Typically, fungal species that cause latent infections can also cause wound infections near or after harvest in the same fruit commodity under certain conditions, but the opposite is not true, and many economically important wound pathogens can only infect fruit if its peel is broken, therefore they are known as strict wound pathogens. This is the case of Penicillium spp., the causal agents of blue or green molds on many relevant fruit commodities. 
For example, blue mold, caused by the species Penicillium expansum L., can lead to significant postharvest losses of apple, pear, stone fruits, kiwifruit, many berries, pomegranate, persimmon, and other subtropical and tropical fruits [3-5]. The two postharvest diseases that account for the largest decay losses of citrus fruits worldwide are green and blue molds, caused by Penicillium digitatum (Pers.:Fr.) Sacc. and Penicillium italicum Wehmer, respectively [6]. It is clear from these denominations that the common names of postharvest diseases are based on the symptoms they produce. Other important wound pathogens are Geotrichum spp., which cause sour rot on different horticultural products, and Rhizopus spp., which are dangerous postharvest pathogens that cause soft rot or Rhizopus rot on a wide range of fruit hosts. The most important species are Geotrichum candidum L., which attacks stone fruits such as peach, nectarine, plum, and sweet cherry, but also tomato and other fruit-like vegetables; and Geotrichum citri-aurantii (Ferraris) Butler, the cause of sour rot of citrus fruits. Rhizopus stolonifer (Ehrenb.) Vuill. is the most important species causing fruit soft rot [7-9].

Among latent pathogens, Botrytis cinerea Pers.:Fr., which causes gray mold, is the main causal agent of postharvest decay of grape, strawberry, blueberry and other small berries, kiwifruit, pomegranate, fig, etc., but also attacks many other fruits and vegetables [10,11]. Colletotrichum spp. cause anthracnose on many subtropical and tropical fruits, such as citrus fruit, avocado, persimmon, banana, papaya, mango, and pineapple. The most important species are C. gloeosporioides (Penz.) Penz. \& Sacc., C. acutatum J.H. Simmonds, and C. horii B.S. Weir \& P.R. Johnst. [12,13]. Alternaria spp., which causes black spot, and Lasiodiplodia theobromae (Pat.) Griffon and Maubl. and other Botryosphaeriaceae pathogens, which cause stem-end rot, are also economically relevant for the worldwide industry of subtropical and tropical fruit crops [14,15]. The species Alternaria alternata (Fr.) Keissl. is also an important postharvest pathogen of pome fruits, persimmon, loquat, and pomegranate, among many other fruits [16]. Species of Monilinia, especially M. fructicola (Winter) Honey, M. laxa (Aderhold \& Ruhland) Honey, and M. fructigena (Aderhold \& Ruhland) Honey, cause field and postharvest brown rot of stone fruits and are generally considered among the most substantial limiting factors of the yield of these fruit crops [17]. Monilinia spp. can also cause postharvest disease on pome fruits [18].

For many years now, fruit postharvest diseases and the economic losses they cause have been contained worldwide through postharvest applications of synthetic chemical fungicides in commercial packinghouses. Active ingredients such as imazalil (IMZ), pyrimethanil (PYR), fludioxonil (FLU), thiabendazole (TBZ), and others are being extensively used as cost-effective means of postharvest decay control in conventional horticulture. However, the massive and continuous use of these chemicals is increasingly leading to significant problems, such as human health issues and environmental contamination due to chemical residues, reduced efficacy of many synthetic fungicides due to the proliferation of resistant fungal biotypes, and restricted access to new high-value organic markets or traditional export markets that are now demanding products with lower levels of pesticides to satisfy consumer demands. Therefore, consumer trends and legislative updates clearly favor a reduction in the use of conventional fungicides, which makes it necessary to potentiate research to develop and implement alternative approaches and novel technologies for the control of postharvest diseases. If conventional chemicals are not available, effective control will need to adopt integrated strategies in which, besides new nonpolluting postharvest antifungal treatments, all factors affecting disease epidemiology and incidence will need to be taken into account, including preharvest factors $[19,20]$. Such a "nonpolluting integrated disease management" (NPIDM) concept should not be confused with the traditional "integrated disease management" (IDM) in the context of agricultural "integrated production," which often implies fruit production in compliance with particular national or regional regulations and programs that still include the use of postharvest fungicides. In Valencia (Spain), for instance, the regional administrative rule for IDM of citrus fruit allows the use of postharvest conventional fungicides "when necessary," and the only restriction is that they have to be applied "under technical supervision" [21]. 
The establishment of NPIDM strategies against target postharvest diseases is based on the knowledge of pathogen biology and epidemiology and needs to consider all preharvest, harvest, and postharvest factors that can influence disease appearance and incidence in order to minimize decay losses. Of course, all the actions planned, in the field or after harvest, should be cost-effective and not adversely affect fruit quality. It is clear in this context, especially in the case of diseases caused by wound pathogens, that the basis of successful NPIDM strategies is the commercial adoption of suitable nonpolluting postharvest antifungal treatments to replace the use of conventional postharvest fungicides. In general, according to their nature, these alternative treatments can be physical, chemical, or biological [6,19]. Chemical alternatives should be compounds with known and minimal toxicological effects on mammals and impact on the environment and, as substances that will be in contact with fresh produce, they should be affirmed as generally recognized as safe (GRAS) by the United States Food and Drug Administration (US FDA), as food additives by the European Food Safety Authority (EFSA), or as an equivalent status by national legislations of other countries. GRAS materials are exempt from residue tolerances on all agricultural commodities by the US FDA. Low-toxicity chemicals that are recognized as GRAS include some essential oils, plant extracts, and other natural compounds of varying composition, but also synthetic inorganic or organic salts such as carbonates, bicarbonates, sorbates, benzoates, acetates, paraben salts, silicates, etc. [22]. When compared to other GRAS compounds, the advantages of these salts are their great availability, ease of handling and use, and low cost. Research methods for evaluating the suitability of these kinds of salts as alternative treatments for the control of postharvest diseases of fresh fruits, as well as noteworthy research results and successful commercial applications, are described in this review.

\section{Evaluation and Selection of GRAS Salts}

Although the acidic forms of some GRAS salts can also show substantial antimicrobial activity, salt compounds are preferred as potential postharvest treatments because of their superior solubility and ease of manipulation and application. Moreover, the additional antifungal activity against important postharvest pathogens of cations such as $\mathrm{Na}+, \mathrm{K}+$, and $\mathrm{NH} 4+$ has been proven for many salts [23,24].

Research with GRAS salts to control fruit postharvest decay generally implies a sequential procedure. In vitro tests are useful to assess the toxicity of different salt concentrations to the target postharvest pathogen. Aqueous solutions of selected salts at selected concentrations can then be used in in vivo laboratory tests, with fruit artificially inoculated with pathogens to determine the control ability of the salt in conditions that resemble potential applications in the packinghouse. The commercial value of the potential implementation of postharvest treatments with selected salt solutions at selected concentrations can be tested afterwards in semicommercial or commercial trials. More recently, interest has grown with regard to the use of antifungal GRAS salts as ingredients of edible coatings. In the fresh fruit industry, such coatings are devoted for increased storage life, but also as a substitute for the prestorage waxes that are often applied in mixed formulations with conventional fungicides.

\subsection{In Vitro Antifungal Activity}

Given a postharvest disease of economic importance, its causal microorganism should be isolated from diseased fruit, purified, properly identified, and multiplied to be used in the experiments. Postharvest fungal pathogens are typically cultured and multiplied on Petri dishes containing potato dextrose agar (PDA) culture medium, although other media such as malt extract agar (MEA), V-8, or dichloran rose-bengal chloramphenicol agar (RBDC) may be used. Commonly, different strains of the same pathogen are isolated from infected fresh fruits found in commercial packinghouses in the commodity producing area, and preliminary in vivo tests are conducted to select, based on their aggressiveness and uniform behavior, those strains of each species more suitable for use in research. Appropriate incubation temperatures for growth of the most common postharvest pathogens of fresh fruit are between 20 and $25^{\circ} \mathrm{C}$. Depending on the growth rate of the fungal species, the incubation time needed to obtain mature fungal inoculum for use in experiments is 1-3 weeks. 
The most typical procedure for in vitro evaluation of the antifungal activity of GRAS salts is to assess the inhibition of the radial mycelial growth of the target pathogen. For this, the fungus is inoculated on $90 \mathrm{~mm}$ diameter plastic Petri dishes with PDA medium amended with the test salt at the desired concentration. Since the solubility in water of most GRAS salts is very high, sterile stock solutions of each salt at high concentration (5-10\%) are prepared and serial dilutions are performed to achieve the range of final concentrations that will be tested, frequently from $0.1 \%$ or lower to a maximum of $2-3 \%$, depending on the salt characteristics and the regulations established for each of them. These solutions are then incorporated into the autoclaved PDA medium at $40-50{ }^{\circ} \mathrm{C}$, poured into the Petri dishes, and allowed to solidify, all under strict sterile conditions. Spores at a known concentration or, more commonly, mycelial plugs (around $5 \mathrm{~mm}$ in diameter) from the edge of the pathogen growing cultures, produced with a sterilized cork borer, are then inoculated at the center of each dish. PDA plates without salt serve as negative controls. Inoculated plates are then incubated in a growth cabinet at $20-25^{\circ} \mathrm{C}$ for a period of time that depends on the fungal species, but at least until fungal growth completely covers the control plates. Radial mycelial growth is periodically (every 1, 2, or 3 days) determined in each plate by measuring two perpendicular fungal colony diameters during the entire incubation period. Usually, 3-5 replicate plates are used for each salt and salt concentration. The results are expressed as a percentage of mycelial growth inhibition according to the formula $(\mathrm{dc}-\mathrm{dt}) / \mathrm{dc} \times 100$, where $\mathrm{dc}$ is the average diameter of the fungal colony on control plates and $\mathrm{dt}$ is the average diameter of the fungal colony on treated (salt-amended) plates. The obtained data are typically subjected to a two-way analysis of variance (ANOVA) with salt and salt concentration as factors. With particular salts selected for their high antifungal activity, it can be useful to establish the minimum inhibitory concentration (MIC) of the salt, which implies testing a larger number of concentrations.

Other valuable information that can be obtained in in vitro tests is the ability of GRAS salts to kill or inactivate the spores of the target fungal pathogen. For this, typical in vitro spore mortality or spore germination tests consist of preparing liquid culture medium (PDA broth or similar) containing different concentrations of the GRAS salt, to which aliquots of a spore suspension of known density (usually $10^{4}-10^{6}$ spores $/ \mathrm{mL}$ ) are aseptically transferred [24,25]. After $18-24 \mathrm{~h}$ of incubation at $20-25^{\circ} \mathrm{C}$, acid fuchsin solution is added to stop further germination and the percentage of germinated spores is determined by observing 100-150 spores with an inverted compound microscope with a micrometer. As a control, the same amount of spore suspension is added to medium broth without GRAS salt. A spore is scored as germinated if the germ tube length is equal to or exceeds that of the spore itself. The data are generally expressed as percent spore germination inhibition and calculated with a formula similar to that described above for the percent mycelial growth inhibition. Each treatment (each salt at a defined concentration) is applied to 3-5 replicates. Microwell plates are often used for this type of test. With particular salts selected for their high antifungal activity, it can be useful to determine the $\mathrm{ED}_{50}$ or $\mathrm{ED}_{95}$ values, i.e., the effective doses (salt concentrations) that kill or inactivate $50 \%$ or $95 \%$, respectively, of the spores.

\subsection{Control Ability of Aqueous Solutions}

GRAS salts and concentrations that show significant antifungal activity in in vitro tests are selected for evaluation of their ability to control disease in in vivo tests, i.e., in the fruit host. The commercial potential of postharvest treatment with aqueous solutions of salts with antifungal properties is high, because their use in fresh produce packinghouses to substitute for conventional fungicides will not require substantial changes in the mode of application and in the industrial equipment used. Like fungicides, they could be applied in drenchers or in the packing line as dips, sprays, or low-pressure floods.

Different types of in vivo tests can be designed, depending on the objective and scale of each particular research step. Sequentially, it is common to start with in vivo primary screenings in the laboratory, continue with small-scale trials, and finish with semicommercial or commercial trials [26]. 
The scale and the amount of fruit employed in each of these types of experiments are larger than in the previous one. Fruits are usually collected from commercial orchards or from the packinghouse if no postharvest treatments have been applied yet. They are used in the experiments the same day or following days, or, depending on the commodity, they could be used after a variable, but not prolonged, period of cold storage. It is important before each experiment to properly select, randomize, wash and disinfect, and thoroughly rinse the fruit.

\subsubsection{In Vivo Primary Screenings}

This denomination is usually given to very small-scale laboratory tests designed to select the best GRAS salts and salt concentrations for a particular type of fruit species or cultivar. Previous information from in vitro tests is useful as a starting point, but experience shows that the efficacy of treatments applied to fruit often cannot be anticipated from the results obtained with pathogens growing in artificial media. Disease development in fruit is the result of complex interactions between host, pathogen, and environment. In the case of diseases caused by wound pathogens, the inhibitory ability of GRAS salts depends on the presence of residues within the wound infection sites occupied by the fungus and on interactions between this residue and constituents of the rind. Apparently, the nature of such interactions may alter the original toxicity of the salts to the pathogen, and therefore their control ability cannot be predicted by their activity in vitro $[26,27]$. For this reason, in some cases, the in vitro toxicity of substances is not preliminarily assessed and in vivo primary screenings are the first approach to select effective GRAS salts and concentrations.

In general, two kinds of antifungal activity can be assessed in in vivo primary screenings (and also in subsequent small-scale trials, explained below): curative activity, in which fruits artificially inoculated with pathogens are treated with the salt solution after different periods of time, and preventive or protective activity, in which fruits treated with salt solution are artificially inoculated with pathogens after different periods of time [28-30]. A period of $24 \mathrm{~h}$ is frequently used for diseases caused by wound pathogens, since it is similar to the time between the most frequent infections in the field, which occur at harvest time, and potential treatment in the packinghouse [31].

A highly concentrated sterile mother solution of the salt is prepared to obtain, by dilution, the desired concentrations to be tested. The salt solution is applied with a micropipette $(30-50 \mu \mathrm{L})$ in wounds inflicted in the rinds of mature fruit a specific period of time after (for assessment of curative activity) or before (for assessment of preventive activity) artificial inoculation of the target pathogen in these rind wounds. Typically, conidial suspensions of known concentration $\left(10^{4}\right.$ to $10^{6}$ spores $\left./ \mathrm{mL}\right)$ are prepared from young PDA fungal cultures (incubation of 7-21 days at $20-25^{\circ} \mathrm{C}$ ) dispersed in Tween $80^{\circledR}$, filtered through two layers of cheesecloth to separate hyphal fragments, and adjusted to the desired concentration using a hemocytometer. Fungal inoculation is performed by applying a small volume $(10-30 \mu \mathrm{L})$ of the conidial suspension to the rind wound. In other cases, the rind wound and the inoculation are performed at the same time by immersing the tip of a sterile stainless steel rod in the conidial suspension and inserting it into the fruit rind. Control fruits are inoculated and treated with sterile distilled water. Depending on the fruit size and shape, one or more rind wounds per fruit can be inflicted. The usual sample size for this type of test is $2-4$ replicates of 5-10 fruits each. Treated fruits are incubated at $20-25^{\circ} \mathrm{C}$ and high relative humidity (RH) for a variable period of time (until most of control fruits are actually decayed), which can be approximately of 1-3 weeks at these incubation conditions. Disease incidence (percentage of infected wounds) and severity (lesion diameter, in $\mathrm{mm}$ or $\mathrm{cm}$ ) and pathogen sporulation (percentage of lesions showing spores) are determined every 3-7 days. Results can be also expressed as percent reductions with respect to control fruit, especially if results from several independent experiments are compiled [31].

\subsubsection{Small-Scale Trials}

Small-scale trials are typically conducted with fresh fruit artificially inoculated with the target pathogen to establish the best postharvest treatment conditions that resemble potential commercial 
applications in fresh produce packinghouses. In general, dip treatments are evaluated for research purposes with aqueous solutions of GRAS salts, because, compared to other aqueous or wax applications, dipping is the most effective method. This is also true for the application of conventional postharvest fungicides [32]. However, in some cases, other application systems such as drenching, high-pressure spraying, or low-pressure rinsing can be tested. Depending on the experiment and the commodity, inoculated and treated fruit can be incubated at $20-25^{\circ} \mathrm{C}$ to favor fast fungal development and obtain results in about 1-2 weeks. This procedure for evaluation of dips in solutions of GRAS salts for the control of postharvest diseases is illustrated in Figure 1. The example in the figure refers to citrus green mold caused by P. digitatum. In other experiments, fruit dipped in salt solution can be stored at low temperatures for longer periods to resemble commercial fruit handling. Again, both curative and preventive activities can be tested in this type of experiment. Since aqueous solutions of GRAS salts are often synergistic with heat for disease control [22,33], dip treatments of different lengths (30 $\mathrm{s}$ to $3 \mathrm{~min})$ with solutions heated at different temperatures $\left(45-60^{\circ} \mathrm{C}\right) \mathrm{can}$ be tested. For example, a stainless steel water tank fitted with electrical resistances and a thermostat, able to heat fruit placed in steel buckets, is used at the Centre de Tecnologia Postcollita of the Institut Valencià d'Investigacions Agràries (IVIA CTP) for this purpose (Figure 1) [34]. Control fruits are typically treated with water at $20{ }^{\circ} \mathrm{C}$ for $30-60 \mathrm{~s}$. The usual sample size for these trials is $3-5$ replicates of $20-25$ fruits each. Treated fruits are commonly arranged in plastic cavity sockets on cardboard or plastic trays before incubation or cold storage. Disease incidence and severity and pathogen sporulation are periodically determined during these storage periods.

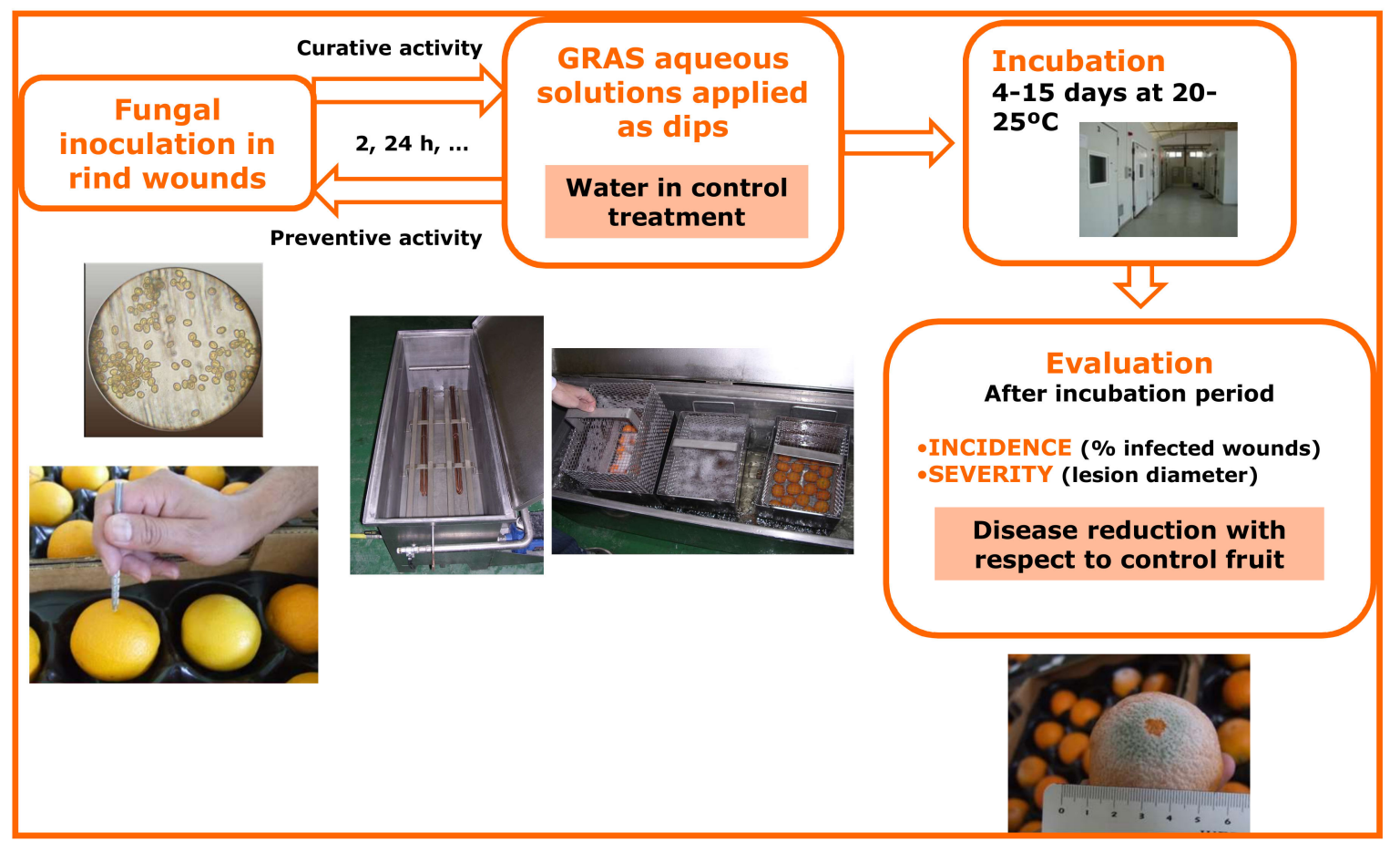

Figure 1. Methodological procedure for evaluating in small-scale trials the ability of dips in aqueous solutions of generally recognized as safe (GRAS) salts to control postharvest green mold of citrus caused by the fungus Penicillium digitatum.

\subsubsection{Semicommercial or Commercial Trials}

As a final conclusive step to assess the potential industrial value of GRAS salt application, semicommercial or commercial trials can be conducted with naturally infected fruits (not artificially inoculated with a target pathogen) and larger sample sizes than in previous trials. Pilot plants with research facilities and equipment, such as fruit packing lines or drenchers that are small-scale versions of those in commercial packinghouses, are used for semicommercial trials, with samples of varied 
size depending on the type of fruit commodity, e.g., 3-5 replicates of 100-300 fruits per treatment. Commercial trials are directly conducted in industrial facilities with several replications per treatment of various entire fruit field boxes, bins, or packages. Besides the mandatory negative control treatment, which is fruit treated with water, it is frequent in these trials to add a positive control treatment consisting of the most common conventional postharvest fungicide, in order to compare the efficacy of the experimental treatments with that of current industrial practices. In every case, treated fruits are commercially handled in the packinghouse and follow the same postharvest handling steps as fruits used for actual commercialization (grading, cold storage, etc.). The performance of GRAS treatments is determined in terms of reduction of total decay, reduction of particular diseases, and effects on the quality of commercial produce.

\subsubsection{Data Analysis}

Dependent variables used to assess the effectiveness of GRAS salts in the above trials are disease incidence and severity and pathogen sporulation, or these variables expressed as percentages of reduction with respect to control fruit, which allow combining results from different analog trials. Depending on the experiment, additional variables that may be taken into account are incidence and severity of potential phytotoxicity induced to the fruit peel by the treatment, and fruit quality attributes during the cold storage period and after shelf life. Depending on the nature of the response variables, different statistical approaches can be selected for data analysis. A generalized linear model (GLM), such as binary logistic regression, or multifactor ANOVA followed by means separation tests are typically used.

\subsection{Performance of Ingredients of Edible Coatings}

Another application of antifungal GRAS salts that is increasingly gaining importance is as ingredients of edible coatings for fresh fruit. Postharvest application of these coatings could replace the use of fungicide-amended commercial waxes applied to many fruit commodities and could be used for organic or "zero-residue" fresh fruit production systems.

Waxes and coatings in general are primarily applied to fresh fruits to increase their postharvest life by regulating the exchange of water and gases (oxygen and carbon dioxide). This primary function allows for less weight loss during storage and, in some cases, the alleviation of some postharvest physiological disorders such as chilling injury or rind breakdown. In addition, coatings can also provide shine and gloss to improve the fruit's external appearance [35]. Besides natural coatings such as chitosan and Aloe spp. gels, most coatings are synthetic formulations comprising blends of hydrocolloids (proteins or polysaccharides) and lipids (waxes, acylglycerols, or fatty acids) as constituents of the composite coating matrix. These main ingredients are typically formulated with plasticizers (e.g., sucrose, glycerol, sorbitol, propylene glycol, etc.) and emulsifiers (e.g., fatty acids, polysorbates, monostearates, lecithin, etc.) to enhance the coating integrity and emulsion stability, respectively. Resins such as shellac are also often added to provide gloss [36,37]. Furthermore, additional ingredients can be incorporated to increase the functionality of these synthetic coatings. Among them, antimicrobial agents, such as some GRAS salts, can be added to prevent or reduce decay during storage [2,36].

The performance of antifungal edible coatings should be evaluated considering the interactions among all the elements of the system, i.e., the target pathogen, the coating ingredients, the antifungal GRAS salt, and the commodity and its postharvest handling. Therefore, developing these coatings requires initial optimization of coating formulations based on the chemical compatibility of the ingredients to achieve stable emulsions capable of forming homogeneous coatings. For a particular fruit commodity, the matrix and the non-antifungal ingredients of the coating are selected according to the coating's physiological activity in terms of reducing weight loss and increasing storability. For a particular pathosystem, GRAS salts and concentrations are initially selected in accordance with the control ability of aqueous solutions, hence it is important that previous information on these 
aspects is available. Coating formulation is usually optimized on the basis of percent total solid content, total lipid content, and GRAS salt concentration, but other parameters such as viscosity, $\mathrm{pH}$, and wettability for the particular fruit commodity are also important [38]. Formulations that are stable after incorporation of the selected salt at the selected concentration in the selected coating will then be tested to determine their ability to control the target postharvest disease. Incompatible emulsions solidify or show phase separation or undesirable physical characteristics. It can happen that a particular salt is not compatible at all with a particular coating, or that it is compatible only at salt concentrations or coating total solid contents below a specific threshold. For example, among 470 emulsions formulated with a hydroxypropyl methylcellulose (HPMC)-lipid (beeswax and shellac) matrix and about 30 antifungal food additives (mostly GRAS salts) and mixtures at a large range of concentrations, only 25 emulsions were selected for their high stability. They contained 6 to $8 \%$ solid content, $50 \%$ (dry basis) total lipid content, and a maximum of $2.5 \%$ (wet basis) food preservative [38].

Although the antifungal activity of stable coatings with GRAS salts may be tested in vitro (disk diameter tests) by preparing dry disks of coating film and placing them on the surface of culture medium previously inoculated with spores of the target pathogen, it is more practical and usual to evaluate the control ability of the coatings in in vivo tests. Figure 2 represents a schematic diagram for this type of experiment, particularly for the evaluation of HPMC-lipid edible coatings containing GRAS salts for the control of black spot on cherry tomato. Fresh fruit samples are selected, washed, artificially inoculated with the target pathogen, and, after about $24 \mathrm{~h}$ (curative activity), coated with the different coating treatments and allowed to dry on a mesh screen. Coatings are usually applied by fruit immersion for brief periods (10-30 s) [39], but they can also be applied by pipetting a small amount of the emulsion $(0.1-0.5 \mathrm{~mL}$, depending on the commodity) onto each fruit and rubbing manually with gloved hands to mimic coating application in industrial packing line roller conveyors [40]. Control fruits are inoculated, but are uncoated or treated with coatings formulated without GRAS salts. Depending on the experiment and the commodity, inoculated and treated fruits can be incubated at $20-25^{\circ} \mathrm{C}$ or cold-stored, similar to commercial postharvest handling. Sample size, dependent variables, and statistical analyses used for this kind of in vivo trial are equivalent to those described above for the in vivo evaluation of GRAS salt aqueous solutions.

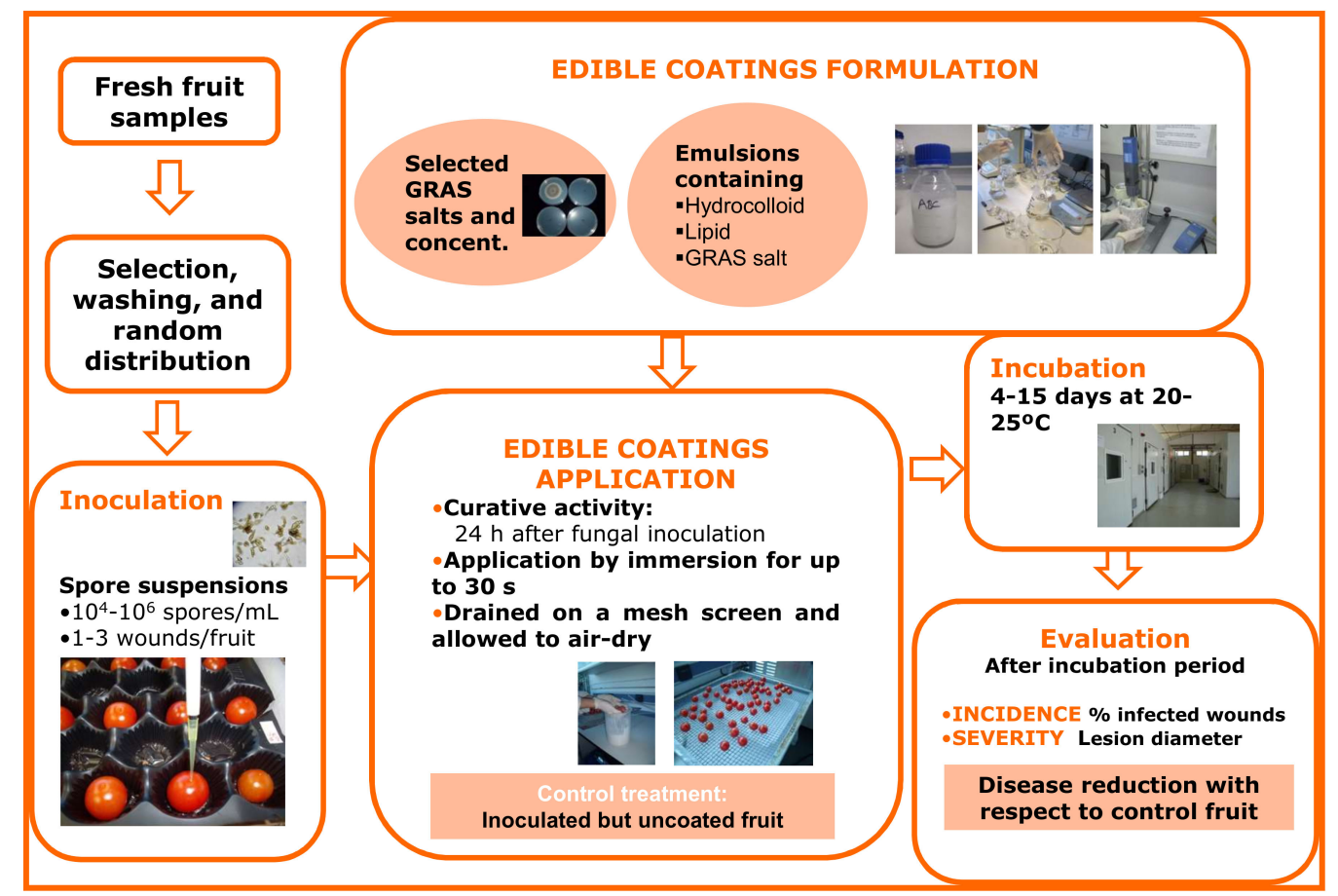

Figure 2. Methodological procedure for formulation and in vivo evaluation of the ability of edible coatings containing GRAS salts to control black spot of tomato caused by the fungus Alternaria alternata. 
Once the coatings with the greatest ability to control disease are identified, and as a last step for the selection of the most feasible antifungal coatings for each particular application, it is very important to determine the effect of coating application on the physiological behavior and overall quality of coated fruit. For this purpose, both physicochemical and sensory fruit quality attributes are periodically evaluated during and after cold storage and simulated periods of shelf life at $20{ }^{\circ} \mathrm{C}$ [41]. Typically, the physicochemical fruit quality attributes that are assessed include weight loss (percent loss with respect to initial weight), fruit firmness (different types of measures with texturometers or penetrometers depending on the commodity), respiration and/or internal gas concentration $\left(\mathrm{O}_{2}\right.$ and $\mathrm{CO}_{2}$ by gas chromatography), and overmaturation volatiles (ethanol and acetaldehyde contents by gas chromatography). Sensory fruit attributes such as flavor, off-flavors, and external and internal visual appearance should be evaluated by several trained judges with expertise in each particular commodity. In some cases, consumer tests by some nontrained individuals can also be of value.

\section{Noteworthy Research and Commercial Results Obtained with GRAS Salts}

Our research group at the IVIA CTP has worked for many years on evaluating GRAS salts for the control of fresh fruit postharvest decay. In vitro tests for preliminary selection of GRAS salts with activity against strains of $B$. cinerea and A. alternata pathogenic to cherry tomato fruit were performed in collaboration with researchers from Brazil [42], and against strains of $M$. fructicola pathogenic to plum fruit in collaboration with researchers from Turkey (Table 1) [43]. Most of the group's work, however, has focused on evaluating the effectiveness of aqueous solutions to control postharvest diseases of fresh fruit of economic importance in the Mediterranean area of the Iberian Peninsula. More recently, we started a research line devoted to developing and selecting edible coatings containing antifungal GRAS salts effective for the control of major postharvest diseases of citrus, stone fruits, tomato, persimmon, and pomegranate.

Table 1. Percentage inhibition of radial growth of Monilinia fructicola on potato dextrose agar (PDA) Petri dishes amended with different concentrations of GRAS salts after 7 days of incubation at $25^{\circ} \mathrm{C}$.

\begin{tabular}{cccc}
\hline \multirow{2}{*}{ GRAS Salt } & \multicolumn{3}{c}{ Inhibition of Monilinia fructicola (\%) $\mathbf{1}$} \\
\cline { 2 - 4 } & \multicolumn{2}{c}{ Salt Concentration (\%, $\boldsymbol{w} / \boldsymbol{v})$} \\
\cline { 2 - 4 } & $\mathbf{0 . 2}$ & $\mathbf{1 . 0}$ & $\mathbf{2 . 0}$ \\
\hline Ammonium carbonate & $100.00 \mathrm{iA}$ & $100.00 \mathrm{eA}$ & $100.00 \mathrm{cA}$ \\
Ammonium bicarbonate & $100.00 \mathrm{iA}$ & $100.00 \mathrm{eA}$ & $100.00 \mathrm{cA}$ \\
Potassium carbonate & $81.76 \mathrm{gA}$ & $100.00 \mathrm{eB}$ & $100.00 \mathrm{cB}$ \\
Potassium bicarbonate & $89.22 \mathrm{hA}$ & $98.01 \mathrm{~dB}$ & $100.00 \mathrm{cC}$ \\
Potassium silicate & $11.08 \mathrm{bA}$ & $100.00 \mathrm{eB}$ & $100.00 \mathrm{cB}$ \\
Potassium sorbate & $49.42 \mathrm{efA}$ & $100.00 \mathrm{eB}$ & $100.00 \mathrm{cB}$ \\
Sodium carbonate & $96.37 \mathrm{hiA}$ & $100.00 \mathrm{eB}$ & $100.00 \mathrm{cB}$ \\
Sodium bicarbonate & $100.00 \mathrm{iA}$ & $100.00 \mathrm{eA}$ & $100.00 \mathrm{cA}$ \\
Sodium acetate & $22.64 \mathrm{cA}$ & $62.21 \mathrm{bB}$ & $93.98 \mathrm{bC}$ \\
Sodium diacetate & $35.83 \mathrm{dA}$ & $100.00 \mathrm{eB}$ & $100.00 \mathrm{cB}$ \\
Sodium benzoate $_{\text {Sodium formate }}$ & $42.34 \mathrm{deA}$ & $91.92 \mathrm{cB}$ & $99.67 \mathrm{cC}$ \\
Sodium propionate & $0.00 \mathrm{aA}$ & $60.44 \mathrm{aB}$ & $92.50 \mathrm{aC}$ \\
Sodium methylparaben ${ }^{2}$ & $54.37 \mathrm{fA}$ & $100.00 \mathrm{eB}$ & $100.00 \mathrm{cB}$ \\
Sodium ethylparaben ${ }^{2}$ & $24.85 \mathrm{cA}$ & $100.00 \mathrm{eB}$ & $100.00 \mathrm{cB}$ \\
\hline
\end{tabular}

Note: Means in rows with different capital letters and means in columns with different lowercase letters are significantly different by Fisher's protected least significant difference (LSD) test $(P<0.05)$ applied after ANOVA. ${ }^{1}$ Colony diameter reduction with respect to control treatments (nonamended PDA plates). ${ }^{2}$ Doses of the agents tested were $0.01,0.05$, and $0.1 \%$. Reproduced from Karaca et al. (2014) [43] with permission from Elsevier.

\subsection{Aqueous Solutions}

Research on the evaluation of aqueous solutions of GRAS inorganic and organic salts for the control of postharvest diseases of fresh horticultural produce has been thoroughly reviewed recently, 
focusing especially on citrus fruit, temperate fruit, tropical fruit, and vegetables [22]. Since then, more interesting works on the subject have been published. The GRAS salt calcium chloride significantly reduced Rhizopus rot of peaches, and the reduction was greater when combined with lemongrass oil [44]. Although not a salt, vapors of the GRAS compound acetic acid were effective for reducing gray mold of stored table grapes caused by $B$. cinerea [45]. Among a wide range of organic acids and salts tested in vitro and in vivo for the control of gray mold of tomato, the salts potassium carbonate, sodium bicarbonate, sodium carbonate, sodium metabisulfite, and sodium salicylate were selected for their higher control ability on fruit artificially inoculated with B. cinerea [25]. Sodium bicarbonate also satisfactorily controlled black rot of yellow pitahaya caused by A. alternata [46]. Further studies on the mode of action of this salt to control citrus green mold caused by P. digitatum were recently released [47]. Heated solutions of sodium benzoate were effective for the reduction of green mold on artificially inoculated oranges either incubated at $20^{\circ} \mathrm{C}$ or cold-stored at $5{ }^{\circ} \mathrm{C}$ [48].

Arguably, one field where the use of GRAS salt solutions has been commercially implemented with greater success is the control of citrus postharvest green and blue molds caused by P. digitatum and P. italicum, respectively. Taking into account early initial data from the 1920s in California [49], intense research was conducted in the 1990s and 2000s to set the basis of commercial dips with sodium carbonate and sodium bicarbonate to reduce or replace the use of synthetic fungicides in citrus packinghouses. It was found that $2-3 \%(w / v)$ dip treatments for $60-150 \mathrm{~s}$ were effective, although with differences, on oranges, lemons, and mandarins. These treatments were synergistic with heat, and solutions heated to $40-55^{\circ} \mathrm{C}$ were more effective yet nonphytotoxic [24,33,50,51]. For instance, the influence of solution temperature, salt concentration, and immersion period on disease incidence is shown in Figure 3 for control with sodium carbonate of blue mold caused by P. italicum on Valencia oranges. Since then, and after several successful commercial applications attempted in California, sodium carbonate and sodium bicarbonate have been the most common GRAS salts used for decay control in citrus packinghouses worldwide. Currently, the most usual mode of application is by dipping the fruit in large tanks containing heated solutions of the salts. However, other applications, such as the use of salt solutions in hot water rinsing and brushing (HWRB) equipment [52,53], have also been successfully attempted. In particular, satisfactory decay control was achieved on organic citrus fruit destined for export markets in Europe that had been treated in HWRB machinery in packinghouses in Israel with $2 \%$ sodium bicarbonate solution at $52{ }^{\circ} \mathrm{C}$ for $15 \mathrm{~s}$ (Fallik, personal communication). The production of electrolyzed sodium bicarbonate is another technology, assayed in Italy, that proved to be superior to both electrolyzed water and nonelectrolyzed sodium bicarbonate (regular salt aqueous solution) for the control of citrus green mold [54].

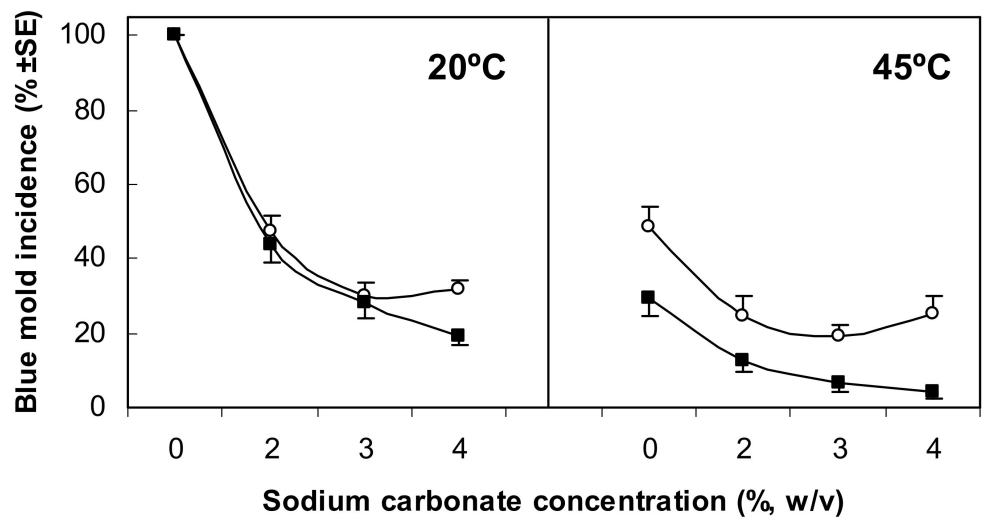

Figure 3. Influence of solution temperature, sodium carbonate concentration, and immersion period ( $\bigcirc=60 \mathrm{~s}, \boldsymbol{\square}=150 \mathrm{~s}$ ) on the incidence of blue mold on cv. Valencia oranges artificially inoculated with Penicillium italicum $24 \mathrm{~h}$ before treatment, rinsed at low pressure, and stored at $20^{\circ} \mathrm{C}$ and $90 \%$ relative humidity (RH) for 7 days. Data are the means of two experiments with five replicates of 25 fruit each. Reproduced from Palou et al. (2001) [51] with permission from the American Phytopathological Society. 
Besides sodium carbonates, another GRAS salt that has repeatedly shown good ability to control citrus postharvest green and blue molds is potassium sorbate. This organic salt has been successfully applied alone or in combination with commercial fungicides in relatively long dip applications (2-3 min) at room or warm temperature [26,55] or in shorter dip applications at higher temperatures $[34,56]$. As in the case of carbonates, potassium sorbate solutions were more effective when applied at high temperatures. Moreover, among a large variety of GRAS salts that were evaluated against the most important postharvest fungal diseases of stone fruit, potassium sorbate was the most effective, particularly for the control of brown rot caused by M. fructicola [57]. Compared to carbonate solutions, potassium sorbate solutions have the advantage of fewer disposal issues due to the absence of sodium and lower salinity and $\mathrm{pH}$, but the disadvantages of higher price and greater phytotoxicity risk (fruit rind staining) if not well applied [34,56]. Probably for these reasons, the commercial use of potassium sorbate aqueous solutions in citrus packinghouses is much less than that of carbonate solutions. However, as discussed in the next subsection, this salt is more used as an antifungal ingredient of fruit coatings.

\subsection{Edible Coatings}

Substantial effort has been devoted in recent years to the development and selection of novel synthetic composite coatings containing GRAS salts as antimicrobial ingredients. Results with such coatings applied for alternative control of postharvest diseases have recently been summarized for fresh produce in general [22] and citrus fruit in particular [2]. Work by our group at the IVIA CTP showed that selected stable HPMC-lipid (beeswax and shellac) coatings formulated with salts or mixtures at concentrations of $0.05-4.5 \%$ (wet basis) substantially reduced green and blue molds on artificially inoculated orange and mandarin cultivars of commercial importance coated and either incubated at $20^{\circ} \mathrm{C}$ for 7 days [39,58] (Figure 4) or cold-stored at $5{ }^{\circ} \mathrm{C}$ for $30-60$ days plus 7 days of shelf life simulation at $20^{\circ} \mathrm{C}[41,59]$. Although the mold control ability of the coatings depended on the citrus species and cultivar, in general those containing the salts potassium sorbate, sodium benzoate, sodium propionate, or mixtures of them were the most effective. In further studies, the physiological performance of these selected coatings was tested during long-term cold storage of noninoculated fruit, and overall, the coatings significantly reduced weight loss and maintained firmness of coated oranges and mandarins. Although the coatings modified the gas composition of the internal atmosphere of coated fruit, they did not affect the fruit sensory quality [41,59]. Furthermore, some of these coatings are also being evaluated with satisfactory results for the control of other important postharvest diseases of citrus such as anthracnose and stem-end rot caused by the fungi C. gloeosporioides and L. theobromae, respectively (Palou, unpublished).

Other similar studies conducted by our group demonstrated the ability of different HPMC-lipid-based coatings containing GRAS salts to control gray mold and black spot of cherry tomato caused, respectively, by B. cinerea and A. alternata [42]. Coatings containing sodium propylparaben, sodium benzoate, or ammonium carbonate salt were the most effective and also reduced weight loss and maintained firmness of cherry tomatoes during cold storage [60,61]. Similarly, among a wide variety of antifungal GRAS salts tested as ingredients of HPMC-beeswax edible coatings, paraben salts and potassium sorbate were found to be the best for effective control of brown rot caused by M. fructicola on artificially inoculated plums [43]. These coatings also effectively reduced weight loss and maintained firmness and overall quality of coated plums during prolonged cold storage [40].

In general, potassium sorbate is the GRAS salt that has shown the best results for fruit decay control when incorporated into matrices of novel edible coatings or when mixed with conventional postharvest waxes [62]. For this reason, several commercial formulations containing this food additive have been registered and are currently available on the market for postharvest treatment of fresh fruit, especially citrus and stone fruits. Citrashine Plus ${ }^{\circledR}$ and Citrashine Plus Nature ${ }^{\circledR}$ from the manufacturer Decco Iberica Postcosecha S.A.U. (Paterna, Valencia, Spain) and Greengard-SK $50^{\circledR}$ from the manufacturer Fomesa Fruitech S.L. (Beniparrell, Valencia, Spain) are examples of this type of product commercialized in Spain. 


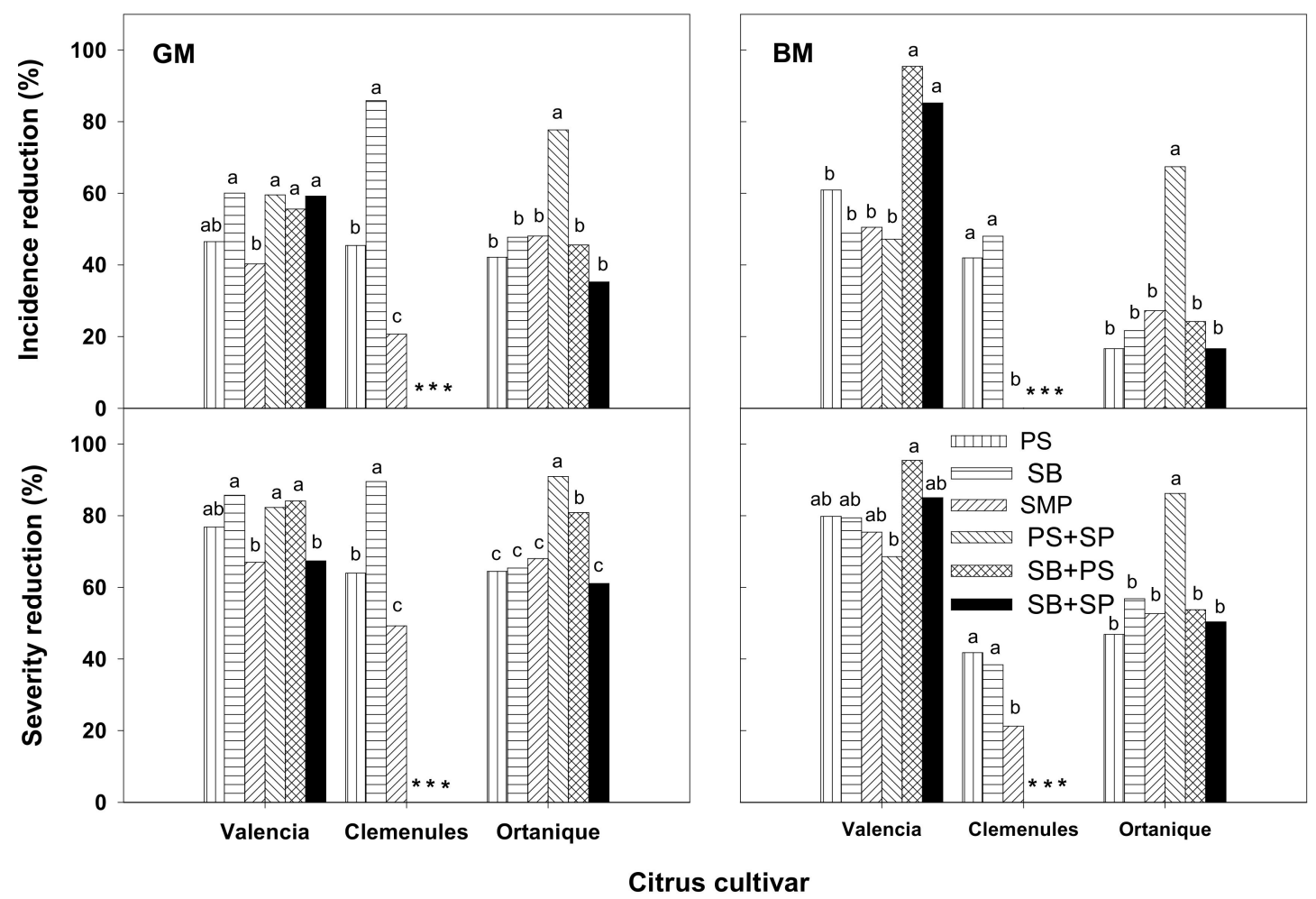

Figure 4. Curative activity of hydroxypropyl methylcellulose (HPMC)-lipid edible composite coatings, containing potassium sorbate (PS), sodium benzoate (SB), sodium propionate (SP), sodium methylparaben (SMP), or a mixture of these, against green (GM) and blue (BM) molds on different citrus cultivars artificially inoculated with Penicillium digitatum and P. italicum, coated $24 \mathrm{~h}$ later, and incubated for 7 days at $20^{\circ} \mathrm{C}$. Disease incidence and severity reductions were determined with respect to control fruit (inoculated but uncoated). For each mold and cultivar, columns with different letters are different by Fisher's protected LSD test $(P<0.05)$. ${ }^{*}$ No data available. Reproduced from Palou et al. (2014) [58] with permission from the International Society for Horticultural Science.

Funding: Catalan, Valencian, and Spanish public agencies, the European Union Commission (FEDER Program), and the IVIA (Montcada, Valencia, Spain) are acknowledged for providing financial support to conduct research on this topic.

Acknowledgments: Thanks to María Bernardita Pérez-Gago for her indispensable and profitable collaboration in the development of edible coatings containing GRAS salts. In memory of Miguel Ángel del Río, for his unconditional friendship, guidance, and support.

Conflicts of Interest: The author declares no conflict of interest.

\section{References}

1. Smilanick, J.L.; Brown, G.E.; Eckert, J.W. The biology and control of postharvest diseases. In Fresh Citrus Fruits, 2nd ed.; Wardowski, W.F., Miller, W.M., Hall, D.J., Grierson, W., Eds.; Florida Science Source: Longboat Key, FL, USA, 2006; pp. 339-396. ISBN 0-944961-08-8.

2. Palou, L.; Valencia-Chamorro, S.A.; Pérez-Gago, M.B. Antifungal edible coatings for fresh citrus fruit: A review. Coatings 2015, 5, 962-986. [CrossRef]

3. Louw, J.P.; Korsten, L. Pathogenic Penicillium spp. on apple and pear. Plant Dis. 2014, 98, 590-598. [CrossRef]

4. Errampalli, D. Penicillium expansum (Blue mold). In Postharvest Decay. Control Strategies; Bautista-Baños, S., Ed.; Academic Press, Elsevier Inc.: London, UK, 2014; pp. 189-231. ISBN 978-0-12-411552-1.

5. Zhang, M.; Xu, L.; Zhang, L.; Guo, Y.; Qi, X.; He, L. Effects of quercetin on postharvest blue mold control in kiwifruit. Sci. Hortic. 2018, 228, 18-25. [CrossRef] 
6. Palou, L. Penicillium digitatum, Penicillium italicum (Green mold, Blue mold). In Postharvest Decay. Control Strategies; Bautista-Baños, S., Ed.; Academic Press, Elsevier Inc.: London, UK, 2014; pp. 45-102. ISBN 978-0-12-411552-1.

7. Barkai-Golan, R. Postharvest Diseases of Fruit and Vegetables. In Development and Control; Elsevier Science: Amsterdam, The Netherlands, 2001; ISBN 978-0-44-450584-2.

8. Bautista-Baños, S.; Bosquez-Molina, E.; Barrera-Necha, L.L. Rhizopus stolonifer (Soft rot). In Postharvest Decay. Control Strategies; Bautista-Baños, S., Ed.; Academic Press, Elsevier Inc.: London, UK, 2014; pp. 1-44. ISBN 978-0-12-411552-1.

9. Saito, S.; Xiao, C.L. Prevalence of postharvest diseases of mandarin fruit in California. Plant Health Progress 2017, 18, 204-210. [CrossRef]

10. Droby, S.; Lichter, A. Post-harvest Botrytis infection: Etiology, development and management. In Botrytis: Biology, Pathology and Control; Elad, Y., Williamson, B., Tudzynski, P., Delen, N., Eds.; Kluwer Academic Publishers: Dordrecht, The Netherlands, 2004; pp. 349-367. ISBN 1-4020-2624-2.

11. Romanazzi, G.; Feliziani, E. Botrytis cinerea (Gray mold). In Postharvest Decay. Control Strategies; Bautista-Baños, S., Ed.; Academic Press, Elsevier Inc.: London, UK, 2014; pp. 131-146. ISBN 978-0-12-411552-1.

12. Prusky, D.; Freeman, S.; Dickman, M.B. (Eds.) Colletotrichum. In Host Specificity, Pathology, and Host -Pathogen Interaction; APS Press: St. Paul, MN, USA, 2000; ISBN 0-89054-258-9.

13. Siddiqui, Y.; Ali, A. Colletotrichum gloeosporioides (Anthracnose). In Postharvest Decay. Control Strategies; Bautista-Baños, S., Ed.; Academic Press, Elsevier Inc.: London, UK, 2014; pp. 337-371. ISBN 978-0-12-411552-1.

14. Rotem, J. The Genus Alternaria. In Biology, Epidemiology and Pathogenicity; APS Press: St. Paul, MN, USA, 1994; ISBN 0-89054-152-3.

15. Zhang, J. Lasiodiplodia theobromae in citrus fruit (Diplodia stem-end rot). In Postharvest Decay. Control Strategies; Bautista-Baños, S., Ed.; Academic Press, Elsevier Inc.: London, UK, 2014; pp. 309-335. ISBN 978-0-12-411552-1.

16. Troncoso-Rojas, R.; Tiznado-Hernández, M.E. Alternaria alternata (Black rot, black spot). In Postharvest Decay. Control Strategies; Bautista-Baños, S., Ed.; Academic Press, Elsevier Inc.: London, UK, 2014; pp. 147-187. ISBN 978-0-12-411552-1.

17. Martini, C.; Mari, M. Monilinia fructicola, Monilinia laxa (Monilinia rot, brown rot). In Postharvest Decay. Control Strategies; Bautista-Baños, S., Ed.; Academic Press, Elsevier Inc.: London, UK, 2014; pp. $233-265$. ISBN 978-0-12-411552-1.

18. Zhu, X.; Niu, C.; Chen, X.; Guo, L. Monilinia species associated with brown rot of cultivated apple and pear fruit in China. Plant Dis. 2016, 100, 2240-2250. [CrossRef]

19. Palou, L.; Smilanick, J.L.; Droby, S. Alternatives to conventional fungicides for the control of citrus postharvest green and blue moulds. Stewart Postharv. Rev. 2008, 4, 1-16. [CrossRef]

20. Wisniewski, M.; Droby, S.; Norelli, J.; Liu, J.; Schena, L. Alternative management technologies for postharvest disease control: The journey from simplicity to complexity. Postharvest Biol. Technol. 2016, 122, 3-10. [CrossRef]

21. Palou, L. Control integrado no contaminante de enfermedades de poscosecha (CINCEP): Nuevo paradigma para el sector español de los cítricos. Levante Agrícola 2011, 406, 173-183.

22. Palou, L.; Ali, A.; Fallik, E.; Romanazzi, G. GRAS, plant- and animal-derived compounds as alternatives to conventional fungicides for the control of postharvest diseases of fresh horticultural produce. Postharvest Biol. Technol. 2016, 122, 41-52. [CrossRef]

23. Palmer, C.L.; Horst, R.K.; Langhans, R.W. Use of bicarbonates to inhibit in vitro colony growth of Botrytis cinerea. Plant Dis. 1997, 81, 1432-1438. [CrossRef]

24. Smilanick, J.L.; Margosan, D.A.; Mlikota-Gabler, F.; Usall, J.; Michael, I.F. Control of citrus green mold by carbonate and bicarbonate salts and the influence of commercial postharvest practices on their efficacy. Plant Dis. 1999, 83, 139-145. [CrossRef]

25. Alaoui, F.T.; Askarne, L.; Boubaker, H.; Boudyach, E.H.; Aoumar, A.A.B. Control of gray mold disease of tomato by postharvest application of organic acids and salts. Plant Pathol. J. 2017, 16, 62-72. [CrossRef]

26. Palou, L.; Usall, J.; Smilanick, J.L.; Aguilar, M.J.; Viñas, I. Evaluation of food additives and low-toxicity compounds as alternative chemicals for the control of Penicillium digitatum and Penicillium italicum on citrus fruit. Pest Manag. Sci. 2002, 58, 459-466. [CrossRef] [PubMed] 
27. Hwang, L.; Klotz, L.J. The toxic effect of certain chemical solutions on spores of Penicillium italicum and P. digitatum. Hilgardia 1938, 12, 1-38. [CrossRef]

28. Palou, L.; Marcilla, A.; Rojas-Argudo, C.; Alonso, M.; Jacas, J.A.; del Río, M.A. Effects of X-ray irradiation and sodium carbonate treatments on postharvest Penicillium decay and quality attributes of clementine mandarins. Postharvest Biol. Technol. 2007, 46, 252-261. [CrossRef]

29. Moscoso-Ramírez, P.A.; Montesinos-Herrero, C.; Palou, L. Characterization of postharvest treatments with sodium methylparaben to control citrus green and blue molds. Postharvest Biol. Technol. 2013, 77, 128-137. [CrossRef]

30. Moscoso-Ramírez, P.A.; Palou, L. Preventive and curative activity of postharvest potassium silicate treatments to control green and blue molds on orange fruit. Eur. J. Plant Pathol. 2014, 138, 721-732. [CrossRef]

31. Eckert, J.W.; Brown, G.E. Evaluation of postharvest fungicide treatments for citrus fruits. In Methods for Evaluating Pesticides for Control of Plant Pathogens; Hickey, K.D., Ed.; APS Press: St. Paul, MN, USA, 1986; pp. 92-97. ISBN 0-89054-071-3.

32. Smilanick, J.L.; Michael, I.F.; Mansour, M.F.; Mackey, B.E.; Margosan, D.A.; Flores, D.; Weist, C.F. Improved control of green mold of citrus with imazalil in warm water compared with its use in wax. Plant Dis. 1997, 81, 1299-1304. [CrossRef]

33. Palou, L.; Smilanick, J.L.; Usall, J.; Viñas, I. Control of postharvest blue and green molds of oranges by hot water, sodium carbonate, and sodium bicarbonate. Plant Dis. 2001, 85, 371-376. [CrossRef]

34. Montesinos-Herrero, C.; del Río, M.A.; Pastor, C.; Brunetti, O.; Palou, L. Evaluation of brief potassium sorbate dips to control postharvest penicillium decay on major citrus species and cultivars. Postharvest Biol. Technol. 2009, 52, 117-125. [CrossRef]

35. Pérez-Gago, M.B.; Palou, L. Antimicrobial packaging for fresh and fresh-cut fruits and vegetables. In Fresh-Cut Fruits and Vegetables: Technology, Physiology, and Safety; Pareek, S., Ed.; CRC Press: Boca Raton, FL, USA, 2016; pp. 403-452. ISBN 978-1-49-872994-9.

36. Valencia-Chamorro, S.A.; Pérez-Gago, M.B.; del Río, M.A.; Palou, L. Antimicrobial edible films and coatings for fresh and minimally processed fruits and vegetables: A review. Crit. Rev. Food Sci. Nutr. 2011, 51, 872-900. [CrossRef] [PubMed]

37. Han, J.H. Edible films and coatings: A review. In Innovations in Food Packaging; Han, J.H., Ed.; Academic Press, Elsevier Inc.: Amsterdam, The Netherlands, 2014; pp. 213-255. ISBN 978-0-12-394601-0.

38. Valencia-Chamorro, S.A.; Palou, L.; del Rio, M.A.; Pérez-Gago, M.B. Inhibition of Penicillium digitatum and Penicillium italicum by hydroxypropyl methylcellulose-lipid edible composite films containing food additives with antifungal properties. J. Agric. Food Chem. 2008, 56, 11270-11278. [CrossRef] [PubMed]

39. Valencia-Chamorro, S.A.; Pérez-Gago, M.B.; del Río, M.A.; Palou, L. Curative and preventive activity of hydroxypropyl methylcellulose-lipid edible composite coating antifungal food additives to control citrus postharvest green and blue molds. J. Agric. Food Chem. 2009, 57, 2770-2777. [CrossRef] [PubMed]

40. Gunaydin, S.; Karaca, H.; Palou, L.; de la Fuente, B.; Pérez-Gago, M.B. Effect of hydroxypropyl methylcellulose-beeswax composite edible coatings formulated with or without antifungal agents on physicochemical properties of plums during cold storage. J. Food Qual. 2017, 8573549. [CrossRef]

41. Valencia-Chamorro, S.A.; Pérez-Gago, M.B.; del Río, M.A.; Palou, L. Effect of antifungal hydroxypropyl methylcellulose (HPMC)-lipid edible composite coatings on penicillium decay development and postharvest quality of cold-stored 'Ortanique' mandarins. J. Food Sci. 2010, 75, 418-426. [CrossRef] [PubMed]

42. Fagundes, C.; Pérez-Gago, M.B.; Monteiro, A.R.; Palou, L. Antifungal activity of food additives in vitro and as ingredients of hydroxypropyl methylcellulose-lipid edible coatings against Botrytis cinerea and Alternaria alternata on cherry tomato fruit. Int. J. Food Microbiol. 2013, 166, 391-398. [CrossRef] [PubMed]

43. Karaca, H.; Pérez-Gago, M.B.; Taberner, V.; Palou, L. Evaluating food additives as antifungal agents against Monilinia fructicola in vitro and in hydroxypropyl methylcellulose-lipid composite edible coatings for plums. Int. J. Food Microbiol. 2014, 179, 72-79. [CrossRef] [PubMed]

44. Salem, E.A.; Youssef, K.; Sanzani, S.M. Evaluation of alternative means to control postharvest Rhizopus rot of peaches. Sci. Hortic. 2016, 198, 86-90. [CrossRef]

45. Venditti, T.; Ladu, G.; Cubaiu, L.; Myronycheva, O.; D’hallewin, G. Repeated treatments with acetic acid vapors during storage preserve table grapes fruit quality. Postharvest Biol. Technol. 2017, 125, 91-98. [CrossRef] 
46. Vilaplana, R.; Alba, P.; Valencia-Chamorro, S. Sodium bicarbonate salts for the control of postharvest black rot disease in yellow pitahaya (Selenicereus megalanthus). Crop Prot. 2018, 114, 90-96. [CrossRef]

47. Venditti, T.; D’hallewin, G.; Ladu, G.; Petretto, G.L.; Pintore, G.; Labavitch, J.M. Effect of $\mathrm{NaHCO}_{3}$ treatments on the activity of cell-wall-degrading enzymes produced by Penicillium digitatum during the pathogenesis process on grapefruit. J. Sci. Food Agric. 2018, 98, 4928-4936. [CrossRef] [PubMed]

48. Palou, L.; Moscoso-Ramírez, P.A.; Montesinos-Herrero, C. Assessment of optimal postharvest treatment conditions to control green mold of oranges with sodium benzoate. Acta Hortic. 2018, 1194, 221-226. [CrossRef]

49. Barger, W.R. Sodium bi-carbonate as citrus fruit disinfectant. Calif. Citrogr. 1928, 13, 172-174.

50. Smilanick, J.L.; Mackey, B.E.; Reese, R.; Usall, J.; Margosan, D.A. Influence of concentration of soda ash, temperature, and immersion period on the control of postharvest green mold on oranges. Plant Dis. 1997, 81, 379-382. [CrossRef]

51. Palou, L.; Usall, J.; Muñoz, J.A.; Smilanick, J.L.; Viñas, I. Hot water, sodium carbonate, and sodium bicarbonate for the control of postharvest green and blue molds of clementine mandarins. Postharvest Biol. Technol. 2002, 24, 93-96. [CrossRef]

52. Fallik, E. Prestorage hot water treatments (immersion, rinsing and brushing). Postharvest Biol. Technol. 2004, 32, 125-134. [CrossRef]

53. Fallik, E. Hot water treatments of fruits and vegetables for postharvest storage. Hortic. Revs. 2010, 38, 191-212. [CrossRef]

54. Fallanaj, F.; Ippolito, A.; Ligorio, A.; Garganese, F.; Zavanella, C.; Sanzani, S.M. Electrolyzed sodium bicarbonate inhibits Penicillium digitatum and induces defence responses against green mould in citrus fruit. Postharvest Biol. Technol. 2016, 115, 18-29. [CrossRef]

55. Hall, D.J. Comparative activity of selected food preservatives as citrus postharvest fungicides. Proc. Fla. State Hort. Soc. 1988, 101, 184-187.

56. Smilanick, J.L.; Mansour, M.F.; Mlikota-Gabler, F.; Sorenson, D. Control of citrus postharvest green mold and sour rot by potassium sorbate combined with heat and fungicides. Postharvest Biol. Technol. 2008, 47, $226-238$. [CrossRef]

57. Palou, L.; Smilanick, J.L.; Crisosto, C.H. Evaluation of food additives as alternative or complementary chemicals to conventional fungicides for the control of major postharvest diseases of stone fruit. J. Food Prot. 2009, 72, 1037-1046. [CrossRef] [PubMed]

58. Palou, L.; Valencia-Chamorro, S.A.; Pérez-Gago, M.B. Edible composite coatings formulated with antifungal GRAS compounds: A novel approach for postharvest preservation of fresh citrus fruit. Acta Hortic. 2014, 1053, 143-149. [CrossRef]

59. Valencia-Chamorro, S.A.; Palou, L.; Del Río, M.A.; Pérez-Gago, M.B. Performance of hydroxypropyl methylcellulose (HPMC)-lipid edible composite coatings containing food additives with antifungal properties during cold storage of 'Clemenules' mandarins. LWT Food Sci. Technol. 2011, 44, 2342-2348. [CrossRef]

60. Fagundes, C.; Palou, L.; Monteiro, A.R.; Pérez-Gago, M.B. Effect of antifungal hydroxypropyl methylcellulose-beeswax edible coatings on gray mold development and quality attributes of cold-stored cherry tomato fruit. Postharvest Biol. Technol. 2014, 92, 1-8. [CrossRef]

61. Fagundes, C.; Palou, L.; Monteiro, A.R.; Pérez-Gago, M.B. Hydroxypropyl methylcellulose-beeswax edible coatings formulated with antifungal food additives to reduce alternaria black spot and maintain postharvest quality of cold-stored cherry tomatoes. Sci. Hortic. 2015, 193, 249-257. [CrossRef]

62. Youssef, K.; Ligorio, A.; Nigro, F.; Ippolito, A. Activity of salts incorporated in wax in controlling postharvest diseases of citrus fruit. Postharvest Biol. Technol. 2012, 65, 39-43. [CrossRef]

(C) 2018 by the author. Licensee MDPI, Basel, Switzerland. This article is an open access article distributed under the terms and conditions of the Creative Commons Attribution (CC BY) license (http:/ / creativecommons.org/licenses/by/4.0/). 